\title{
PENGARUH CURRENT RATIO, DEBT TO EQUITY RATIO, NET PROFIT MARGIN, DAN PERTUMBUHAN PERUSAHAAN TERHADAP HARGA SAHAM PERUSAHAAN MANUFAKTUR SUB SEKTOR MAKANAN DAN MINUMAN YANG TERDAFTAR DI BEI PERIODE 2016-2019
}

\author{
Tagor Darius Sidauruk \\ Yeni Yulistika Sari \\ tagor.darius@yahoo.com., yennyyulistikasari@gmail.com
}

Fakultas Ekonomi dan Bisnis - Program Studi Akuntansi

Universitas Satya Negara Indonesia

\begin{abstract}
ABSTRAK
Tujuan penelitian ini adalah untuk mengetahui pengaruh Current Ratio, Debt to Equity Ratio, Net Profit Margin dan pertumbuhan perusahaan terhadap harga saham pada perusahaan manufaktur sektor barang konsumsi sub sektor makanan dan minuman di Bursa efek Indonesia (BEI) periode 2016 - 2019.

Penelitian ini menggunakan data sekunder yang diperoleh dari laporan keuangan yang dipublikasikan melalui situs resmi Bursa Efek Indonesia. Metode penarikan sampel yang digunakan adalah dengan metode purposive sampling. Jumlah populasi dalam penelitian ini adalah 25 perusahaan dan yang memenuhi kriteria sampel adalah sebanyak 14 perusahaan.

Hasil penelitian ini menunjukkan bahwa Current Ratio dan Debt to Equity Ratio berpengaruh negatif terhadap harga saham, Net Profit Margin berpengaruh positif terhadap harga saham, dan pertumbuhan perusahaan tidak berpengaruh terhadap harga saham. Sedangkan secara simultan hasil penelitian menunjukkan bahwa Current Ratio, Debt to Equity Ratio, Net Profit Margin dan pertumbuhan perusahaan berpengaruh signifikan terhadap harga saham.
\end{abstract}

Kata Kunci : Current Ratio, Debt to Equity Ratio, Net Profit Margin, Pertumbuhan Perusahaan, Harga Saham. 


\section{PENDAHULUAN}

\section{Latar Belakang}

Untuk dapat bersaing di kemajuan perekonomian dunia seperti saat ini, perusahaan wajib mendukung kinerja perusahaan yang efektif agar sanggup mencapai tujuan perusahaan. Di masa perekonomian saat ini, pelaku usaha membutuhkan tambahan modal yang dapat membantu kinerja operasionalnya. Menawarkan kepemilikan perusahaan kepada masyarakat luas atau publik, ini merupakan salah satu metode bagi perusahaan untuk mendapakan tambahan modal.

Pasar modal merupakan tempat dimana perusahaan dapat mengumpulkan modal dengan cara menawarkan saham kepada publik atau masyarakat luas. Pasar modal juga merupakan sarana yang efektif untuk investor dalam menanamkan modalnya agar mendapatkan keuntungan. Dengan adanya pasar modal, investor dapat memperluas jaringan bisnis dengan memperoleh keuntungan atau deviden dengan menjual beli saham.

Harga saham adalah nilai saham yang ditentukan oleh kekuatan dari penawaran jual beli saham pada mekanisme pasar tertentu dan merupakan harga jual dari investor satu ke investor lainnya. Harga saham yang ditawarkan oleh perusahaan tidak dapat dipastikan setiap tahunnya, sehingga menyebabkan saham tersebut mengalami naik atau turun.

Salah satu perusahaan yang mengalami perubahan harga saham setiap tahunnya yaitu perusahaan manufaktur sektor industri barang konsumsi sub sektor makanan dan minuman. Sektor barang konsumsi sub sektor makanan minuman saat ini mempunyai kemampuan pertumbuhan ekonomi yang cukup besar karena didukung oleh sumber daya alam yang melimpah dan adanya permintaan domestik yang tinggi di dalam sektor ini.

Harga saham yang fluktuatif menjadikan investor pintar dalam menganalisis harga saham karena jika analisisnya salah, investor dapat mengalami kerugian. Seorang investor dapat melihat kinerja perusahaan yang sudah go public dengan cara melihat laporan keuangan yang sudah dipublikasikan untuk umum. Dalam penelitian ini, rasio yang digunakan untuk meneliti tentang harga saham yaitu Current Ratio, Debt to Equity Ratio, Net Profit Margin dan Pertumbuhan Perusahaan.

Beberapa penelitian terkait topik di atas telah dilakukan, namun hasilnya masih menunjukkan ketidak konsistenan. Hasil penelitian yang dilakukan Dwi Fitrianingsih (2018) menunjukkan bahwa Current Ratio berpengaruh signifikan terhadap harga saham, sedangkan menurut Rondonuwu Ester Faleria, dkk (2017) Current Ratio tidak berpengaruh terhadap harga saham.

Untuk variabel Debt to Equity Ratio menurut penelitian yang dilakukan oleh Cristin Oktavia Tumandung, dkk (2017) Debt to Equity Ratio berpengaruh terhadap harga saham, sedangkan untuk penelitian Irawati Junaeni (2017) Debt to Equity Ratio tidak berpengaruh signifikan terhadap harga saham.

Hasil penelitian yang dilakukan oleh Ni Luh Dewi Martiani (2018), Net Profit Margin berpengaruh terhadap harga saham, sedangkan menurut Rondonuwu Ester Faleria, dkk (2017) Net Profit Margin tidak pengaruh terhadap harga saham pada perusahaan manufaktur sub sektor makanan dan minuman. 
Hasil penelitian yang dilakukan Dimita H. Purba (2017) menyatakan bahwa pertumbuhan perusahaan berpengaruh siginifikan terhadap harga saham, sedangkan menurut menurut Ahmad Ridho Fachrizal Chaery (2019) pertumbuhan perusahaan tidak berpengaruh terhadap perubahan harga saham.

Berdasarkan riset gap di atas, peneliti tertarik untuk melakukan penelitian tentang pengaruh Current Ratio, Debt to Equity Ratio, Net Profit Margin dan Pertumbuhan Perusahaan Terhadap Harga Saham pada Perusahaan Manufaktur Sektor Barang Konsumsi Sub Sektor Makanan dan Minuman di Bursa Efek Indonesia (BEI) periode 2016 - 2019.

\section{Rumusan Masalah}

Berdasarkan latar belakang penelitian diatas maka dapat dirumuskan masalah penelitian sebagai berikut:

1. Apakah Current Ratio berpengaruh terhadap Harga Saham?

2. Apakah Debt to Equity Ratio berpengaruh terhadap Harga Saham?

3. Apakah Net Profit Margin berpengaruh terhadap Harga Saham?

4. Apakah Pertumbuhan Perusahaan berpengaruh terhadap Harga Saham?

5. Apakah Current Ratio, Debt to Equity Ratio, Net Profit Margin dan Pertumbuhan Perusahaan berpengaruh terhadap Harga Saham?

\section{Tujuan Penelitian}

1. Untuk mengetahui pengaruh Current Ratio terhadap Harga Saham.

2. Untuk mengetahui pengaruh Debt to Equity Ratio terhadap Harga Saham.

3. Untuk mengetahui pengaruh Net Profit Margin terhadap Harga Saham.

4. Untuk mengetahui pengaruh Pertumbuhan Perusahaan terhadap Harga Saham.

5. Untuk mengetahui pengaruh Current Ratio, Debt to Equity Ratio, Net Profit Margin dan Pertumbuhan Perusahaan terhadap Harga Saham.

\section{LANDASAN TEORI}

\section{Harga Saham}

Harga saham adalah nilai suatu saham yang mencerminkan kekayaan perusahaan yang mengeluarkan saham tersebut, dimana fluktuasinya sangat di tentukan oleh kekuatan permintaan dan penawaran yang terjadi di pasar bursa (pasar sekunder). Semakin banyak investor yang ingin membeli atau menyimpan saham, harganya semakin naik. Sebaliknya semakin banyak investor yang ingin menjual atau melepaskan suatu saham, maka harganya semakin bergerak turun (Sulia 2017).

Menurut Irham (2020), dipergunakannya saham sebagai salah satu alat untuk mencari tambahan dana menyebabkan kajian dan analisis tentang saham begitu berkembang baik secara fundamental dan teknikal.

Analisis Fundamental yaitu mencoba memperkirakan harga saham dimasa yang akan datang dengan mengestimasi nilai faktor - faktor fundamental yang mempengaruhi harga saham dimasa yang akan datang dan menetapkan hubungan variabel tersebut sehingga diperoleh taksiran harga saham. Analisis fundamental menitikberatkan pada rasio keuangan dan kejadian - kejadian yang secara langsung 
maupun tidak langsung mempengaruhi kinerja keuangan perusahaan. Pendekatan yang di pakai oleh peneliti menggunakan analisis fundamental.

Harga saham yang digunakan pada penelitian ini adalah harga saham penutupan yaitu harga yang diminta oleh penjual atau harga perdagangan terakhir untuk suatu periode.

\section{Current Ratio}

Menurut Irham (2020), rasio lancar merupakan ukuran yang umum digunakan atas solvensi jangka pendek, kemampuan suatu perusahaan memenuhi kebutuhan utang ketika jatuh tempo. Kasmir (2018) mengatakan bahwa rasio lacar atau current ratio ini merupakan rasio untuk megukur kemampuan perusahaan membayar jangka pendek atau utang yang segera jatuh tempo pada saat ditagih.

Current ratio yang tinggi maka semakin baiklah posisi kreditor karena terdapat kemungkinan yang lebih besar bahwa utang perusahaan itu akan di bayar pada waktunya.

Penelitian ini menggunakan rumus sebagai berikut (Kasmir, 2018):

$$
\text { Current Ratio }=\frac{\text { Aset Lancar }}{\text { Kewajiban Lancar }}
$$

\section{Debt To Equity Ratio}

Menurut Kasmir (2018), Debt to Equity Ratio merupakan rasio yang digunakan untuk menilai utang dengan ekuitas, rasio ini dicari dengan cara membandingkan antara seluruh utang, termasuk utang lancar dengan seluruh ekuitas. Rasio ini bermanfaat untuk mengetahui jumlah dana yang dsediakan peminjam (kreditor) dengan pemilik perusahaan, jadi dengan kata lain, rasio ini berfungsi untuk mengetahui setiap rupiah modal sendiri yang dijadikan untuk jaminan utang.

Penelitian ini menggunakan rumus sebagai berikut (Kasmir, 2018):

$$
\text { Debt to Equity Ratio }=\frac{\text { Total Kewajiban }}{\text { Ekuitas }}
$$

Debt to Equity Ratio menggambarkan semakin tingginya modal usaha memanfaatkan utang daripada ekuitas dan dapat menunjukkan rasio perusahaan semakin tinggi.

\section{Net Profit Margin}

Menurut Kasmir (2018), Net Profit Margin merupakan margin laba atas penjualan, pengukuran rasio ini dengan cara membandingkan laba bersih setelah pajak dengan penjualan bersih. Menurut Irham (2020), rasio Net Profit Margin disebut juga dengan rasio pendapatan terhadap penjualan.

Penelitian ini menggunakan rumus sebagai berikut (Irham (2020):

$$
\text { Net Profit Margin }=\frac{\text { Earning After Tax }(E A T)}{\text { Sales }}
$$

Net Profit Margin dapat mencerminkan seberapa efektif perusahaan dalam meminimalkan beban-beban operasionalnya. Karna besar kecilnya laba bersih yang diperoleh dari penjualan sangat dipengaruhi oleh kemampuan perusahaan dalam 
menekan beban pokok penjualan, beban operasional, beban umum dan beban beban lainnya.

\section{Pertumbuhan Perusahaan (Company's Growth)}

Pertumbuhan perusahaan sangat diharapkan oleh berbagai pihak baik pihak yang berasal dari internal maupun pihak eksternal perusahaan, dengan bertumbuhnya perusahaan diharapkan dapat memberikan naiknya nilai perusahaan dimata investor, nilai perusahaan biasanya dapat diketahui dari harga saham perusahaan tersebut (Firmansyah 2017).

Untuk pertumbuhan perusahaan bisa di lihat dari kenaikan laba bersih dimana rasio ini menunjukkan kemampuan perusahan meningkatkan laba bersih dibanding tahun lalu.

Penelitian ini menggunakan rumus sebagai berikut (Sofyan (2018):

Kenaikan Laba Bersih $=\frac{\text { Laba bersih tahun ini }- \text { Laba bersih tahun lalu }}{\text { Laba bersih tahun lalu }}$

\section{Desain Penelitian}

\section{METODE PENELITIAN}

Penelitian ini merupakan penelitian kausal, yaitu penelitian yang mencari pengaruh antara satu atau lebih variabel bebas terhadap variabel terikat.

\section{Jenis Data}

Penelitian ini menggunakan data kuantitatif dari data sekunder berupa laporan keuangan perusahaan Manufaktur Sektor Barang Konsumsi Sub Sektor Makanan dan Minuman di Bursa Efek Indonesia (BEI) periode 2016 - 2019.

\section{Populasi dan Sampel}

Populasi yang digunakan dalam penelitian ini adalah perusahaan Manufaktur Sektor Industri Barang Konsumsi subsektor Makanan dan Minuman yang terdaftar di Bursa Efek Indonesia periode 2016 - 2019, dengan Teknik pengambilan sampel terpilih (non-probability sampling) yaitu menggunakan metode purposive sampling. Adapun kriteria pemilihan sampel yang ditentukan dalam penelitian ini adalah sebagai berikut:

1. Jumlah perusahaan manufaktur sektor industri barang konsumsi subsektor makanan dan minuman yang terdaftar di Bursa Efek Indonesia tahun 2016 2019.

2. Perusahaan yang menyajikan laporan keuangan lengkap periode 2016- 2019.

3. Perusahaan yang tidak mengalami kerugian dalam setiap periode penelitian.

\section{Teknik Pengumpulan Data}

Penelitian ini termasuk dalam penelitian kuantitatif dengan menggunakan data sekunder berupa laporan keuangan sebagai sumber data. Data sekunder yang diambil dalam penelitian ini adalah laporan keuangan perusahaan manufaktur sektor barang konsumsi sub sektor makanan dan minuman yang terdaftar di Bursa Efek Indonesia (BEI) periode 2016 - 2019. 


\section{Variabel Penelitian}

Variabel terikat (dependen) dalam penelitian ini adalah Harga Saham. Variabel Independen dalam penelitian ini adalah Current Ratio $\left(\mathrm{X}_{1}\right)$, Debt to Equity Ratio $\left(\mathrm{X}_{2}\right)$, Net Profit Margin $\left(\mathrm{X}_{3}\right)$, dan Pertumbuhan Perusahaan $\left(\mathrm{X}_{4}\right)$.

\section{Hipotesis}

Ho1: Current Ratio tidak berpengaruh terhadap Harga Saham.

Ha1: Current Ratio berpengaruh terhadap Harga Saham.

Ho2: Debt to Equity Ratio tidak berpengaruh terhadap Harga Saham.

Ha2: Debt to Equity Ratio berpengaruh terhadap Harga Saham

Ho3: Net Profit Margin tidak berpengaruh terhadap Harga Saham.

Ha3: Net Profit Margin berpengaruh terhadap Harga Saham

Ho4: Pertumbuhan Perusahaan tidak berpengaruh terhadap Harga Saham

Ha4: Pertumbuhan Perusahaan berpengaruh terhadap Harga Saham

Ho5: Current Ratio, Debt to Equity Ratio, Net Profit Margin dan Pertumbuhan Perusahaan tidak berpengaruh terhadap Harga Saham

Ha5: Current Ratio, Debt to Equity Ratio, Net Profit Margin dan Pertumbuhan Perusahaan berpengaruh terhadap Harga Saham

\section{ANALISIS HASIL DAN PEMBAHASAN}

\section{Statistik Deskriptif}

Tabel 1

Statistik Deskriptif

Descriptive Statistics

\begin{tabular}{|l|r|r|r|r|r|}
\hline & \multicolumn{1}{|c|}{ N } & Minimum & Maximum & \multicolumn{1}{c|}{ Mean } & Std. Deviation \\
\hline Current Ratio & 56 &, 6800 & 8,6400 & 2,467500 & 1,8881614 \\
Debt to Equity Ratio & 56 &, 1600 & 2,6800 &, 906429 &, 6223458 \\
Net Profit Margin & 56 &, 0010 &, 4200 &, 111071 &, 1059276 \\
Pertumbuhan perusahaan & 56 &,- 5900 & 2,0900 &, 210000 &, 4531907 \\
LN Harga saham & 56 & 4,4700 & 9,6800 & 7,744643 & 1,3788137 \\
Valid N (listwise) & 56 & & & & \\
\hline
\end{tabular}

Berdasarkan tabel diatas, hasil analisis dengan menggunakan statistik deskriptif dapat dijelaskan sebagai berikut:

a. Hasil analisis statistik deskriptif terhadap current ratio menunjukkan nilai minimum sebesar 0,68, nilai maksimal sebesar 8,64 dengan rata-rata (mean) lebih besar dari standar deviasi yaitu 2,46 > 1,88 menunjukkan bahwa sebaransebaran nilai current ratio baik. Data tersebut bersifat homogen, tidak ada kesenjangan yang terlalu besar antara nilai terendah dan tertinggi variabel current ratio selama periode penelitian.

b. Hasil analisis statistik deskriptif terhadap debt to equity ratio menunjukkan nilai minimum sebesar 0,16 , nilai maksimal sebesar 2,68 dengan rata-rata (mean) lebih besar dari standar deviasi yaitu 0,90>0,62 menunjukkan bahwa sebaran sebaran nilai debt to equity ratio baik. Data tersebut bersifat homogen, tidak ada kesenjangan yang terlalu besar antara nilai terendah dan tertinggi variabel debt to equity ratio selama periode penelitian. 
c. Hasil analisis statistik deskriptif terhadap Net Profit Margin menunjukkan nilai minimum sebesar 0,001 , nilai maksimal sebesar 0,42 dengan rata-rata (mean) lebih besar dari standar deviasi yaitu $0,11>0,10$ menunjukkan bahwa sebaran sebaran nilai net profit margin baik. Data tersebut bersifat homogen, tidak ada kesenjangan yang terlalu besar antara nilai terendah dan tertinggi variabel Net Profit Margin selama periode penelitian.

d. Hasil analisis statistik deskriptif terhadap pertumbuhan perusahaan menunjukkan nilai minimum sebesar $-0,59$, nilai maksimal sebesar 2,09 dengan rata-rata (mean) lebih kecil dari standar deviasi yaitu $0,21<0,45$ menunjukkan bahwa sebaran sebaran nilai pertumbuhan perusahaan baik. Data tersebut bersifat homogen, tidak ada kesenjangan yang terlalu besar antara nilai terendah dan tertinggi variabel pertumbuhan perusahaan selama periode penelitian.

e. Hasil analisis statistik deskriptif terhadap harga saham menunjukkan nilai minimum sebesar 4,47, nilai maksimal sebesar 9,68 dengan rata-rata (mean) lebih besar dari standar deviasi yaitu 7,74 > 1,37 menunjukkan bahwa sebaran sebaran nilai harga saham baik. Data tersebut bersifat homogen, tidak ada kesenjangan yang terlalu besar antara nilai terendah dan tertinggi variabel harga saham selama periode penelitian.

\section{Hasil Analisis Regresi Linear Berganda}

\section{Analisis Regresi Linear Berganda}

Model regresi linier berganda digunakan untuk menganalisis hubungan sebuah variabel dependen dengan dua atau lebih variabel independen. Berdasarkan hasil pada tabel Coefficients di bawah ini maka dapat dibuat persamaan regresi linier berganda sebagai dibawah ini :

$$
\mathrm{Y}=8,013-0,243 \times 1-0,857 \times 2+9,674 \times 3+0,161 \times 4+\mathrm{e}
$$

Persamaan regresi diatas maka dapat diinterpretasikan sebagai berikut :

a. Konstanta $=8,013$

Jika nilai variabel Current Ratio $\left(\mathrm{X}_{1}\right)$, Debt to Equity Ratio $\left(\mathrm{X}_{2}\right)$, Net Profit Margin $\left(\mathrm{X}_{3}\right)$, dan Pertumbuhan Perusahaan $\left(\mathrm{X}_{4}\right)$ dianggap sama dengan nol (0) maka nilai variabel Harga Saham (Y) 8,013 point.

b. Koefisien $\mathrm{X}_{1}=-0,243$

Jika nilai variabel Current Ratio $\left(\mathrm{X}_{1}\right)$ mengalami kenaikan sebesar satu satuan, sementara Debt to Equity Ratio $\left(\mathrm{X}_{2}\right)$, Net Profit Margin $\left(\mathrm{X}_{3}\right)$, dan Pertumbuhan Perusahaan $\left(\mathrm{X}_{4}\right)$ dianggap tetap, maka akan mempengaruhi penurunan nilai variabel Harga Saham (Y) sebesar 0,243 point.

c. Koefisien $\mathrm{X}_{2}=-0,857$

Jika nilai variabel Debt to Equity Ratio $\left(\mathrm{X}_{2}\right)$ mengalami kenaikan sebesar satu satuan, sementara Current Ratio $\left(\mathrm{X}_{1}\right)$, Net Profit Margin $\left(\mathrm{X}_{3}\right)$, dan Pertumbuhan Perusahaan $\left(\mathrm{X}_{4}\right)$ dianggap tetap, maka akan mempengaruhi penurunan nilai variabel Harga Saham (Y) sebesar 0,857 point.

d. Koefisien $\mathrm{X}_{3}=9,674$

Jika nilai variabel Net Profit Margin $\left(\mathrm{X}_{3}\right)$ mengalami kenaikan sebesar satu satuan, sementara Current Ratio $\left(\mathrm{X}_{1}\right)$, Debt to Equity Ratio $\left(\mathrm{X}_{2}\right)$, dan 
Pertumbuhan Perusahaan $\left(\mathrm{X}_{4}\right)$ dianggap tetap, maka akan mempengaruhi kenaikan nilai variabel Harga Saham (Y) sebesar 9,674 point.

e. Koefisien $\mathrm{X}_{4}=0,161$

Jika nilai variabel Pertumbuhan Perusahaan $\left(\mathrm{X}_{4}\right)$ mengalami kenaikan sebesar satu satuan, sementara Current Ratio $\left(\mathrm{X}_{1}\right)$, Debt to Equity Ratio $\left(\mathrm{X}_{2}\right)$, dan Net Profit Margin $\left(\mathrm{X}_{3}\right)$ dianggap tetap, maka akan mempengaruhi kenaikan nilai variabel Harga Saham (Y) sebesar 0,161 point.

\section{Hasil Uji Asumsi Klasik}

\section{a. Uji normalitas}

Normalitas dapat diketahui dengan menggunakan uji Kolmogorov-Smirnov, caranya dengan membandingkan nilai signifikan yang dicapai oleh variabel bebas dan variabel terikat yang digunakan dalam penelitian dengan taraf signifikasi 0,05 .

Pengujian normalitas residual berdistribusi normal dengan ditunjukkan pada pengujian One - Sample Kolmogrov Smirnov dengan angka Asymp. Sig. (2tailed) sebesar 0.200 lebih besar dari 0,05 , sehingga data penelitian sudah terdistribusi normal.

\section{b. Uji Multikolinieritas}

Pengujian multikolinieritas dalam penelitian ini dengan cara meregresikan model analisis dan melakukan uji kolerasi antar variabel independen dengan menggunakan Tolerance dan Variance Inflation Factors (VIF). Agar tidak terjadi korelasi maka nilai yang harus dipenuhi yaitu nilai tolerance $>0,1$ dan VIF $<10$.

Berdasarkan pengujian yang dilakukan bahwa nilai tolerance dari CR adalah 0,406, DER adalah 0,548, NPM adalah 0,653 dan pertumbuhan perusahaan adalah 0,969 yang mana hasil nilai tolerance diatas 0,1 . Hal ini berarti tidak ada kolerasi antar variabel bebas. Hasil perhitungan VIF dari CR adalah 2,462, DER adalah 1,824, NPM adalah 1,532 dan pertumbuhan perusahaan adalah 1,032 menunjukkan nilai VIF dibawah dari 10 yang juga berarti tidak ada kolerasi dari variabel bebas.

\section{c. Uji Heteroskedastisitas}

Untuk mengetahui ada atau tidaknya heteroskedastisitas dalam model regresi dapat dilihat pada grafik Scaterplot. Jika titik - titik dalam grafik menyebar tidak membentuk pola tertentu, maka tidak terjadi heteroskedastisitas. Berikut ini hasil uji Scaterplot. 


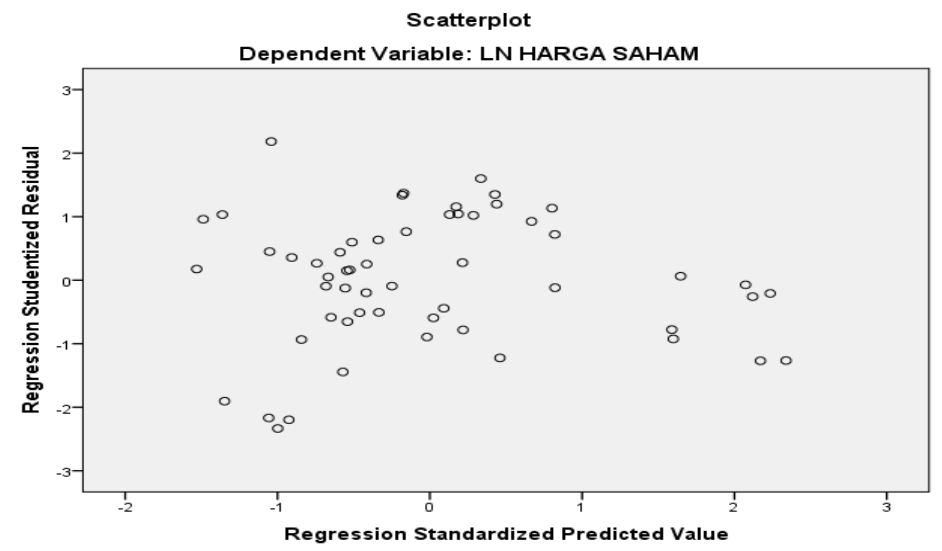

Gambar 1

Hasil Uji Heteroskidastisitas Scatterplot

\section{d. Uji Autokorelasi}

Uji autokorelasi merupakan uji untuk melihat apakah terjadi korelasi antara suatu periode dengan periode sebelumnya. Pengujian ada tidaknya autokorelasi dalam penelitian ini menggunakan Uji Durbin Watson.

Hasil uji autokorelasi didapat nilai Durbin - Watson 0,434 dapat disimpulkan bahwa model regresi linear berganda berada diantara -2 sampai +2 maka dari hasil data tersebut tidak ada autokorelasi atau bebas autokorelasi.

\section{Hasil Uji Hipotesis}

a. Pengujian Hipotesis Parsial (t)

Tabel 2

Hasil Uji t

Coefficients $^{\mathrm{a}}$

\begin{tabular}{|c|c|c|c|c|c|c|c|c|}
\hline \multirow{2}{*}{\multicolumn{2}{|c|}{ Model }} & \multicolumn{2}{|c|}{$\begin{array}{c}\text { Unstandardized } \\
\text { Coefficients }\end{array}$} & \multirow{2}{*}{\begin{tabular}{|c}
$\begin{array}{l}\text { Standardized } \\
\text { Coefficients }\end{array}$ \\
Beta
\end{tabular}} & \multirow[b]{2}{*}{$\mathrm{t}$} & \multirow[b]{2}{*}{ Sig. } & \multicolumn{2}{|c|}{$\begin{array}{l}\text { Collinearity } \\
\text { Statistics }\end{array}$} \\
\hline & & $\mathrm{B}$ & Std. Error & & & & Tolerance & VIF \\
\hline \multirow[t]{5}{*}{1} & (Constant) & 8,013 & ,471 & & 17,023 &, 000 & & \\
\hline & Current ratio &,- 243 & ,116 &,- 333 & $-2,093$ &, 041 & ,406 & 2,462 \\
\hline & Debt to equity ratio &,- 857 & ,303 &,- 387 & $-2,825$ & ,007 &, 548 & 1,824 \\
\hline & Net profit margin & 9,674 & 1,633 &, 743 & 5,924 &, 000 & ,653 & 1,532 \\
\hline & $\begin{array}{l}\text { Pertumbuhan } \\
\text { perusahaan }\end{array}$ &, 161 & ,313 &, 053 &, 515 & ,609 & ,969 & 1,032 \\
\hline
\end{tabular}

a. Dependent Variable: Ln Harga saham

\section{Current Ratio Berpengaruh Negatif Terhadap Harga Saham}

Berdasarkan hasil uji statistik $\mathrm{t}$ pada tabel diatas dapat diketahui bahwa variabel current ratio mempunyai nilai signifikansi sebesar 0,041 lebih kecil dari 0,05 dan mempunyai nilai t hitung -2,093 artinya secara parsial Current Ratio berpengaruh negatif terhadap harga saham. Dalam penelitian ini, bahwa Current Ratio berpengaruh negatif terhadap harga saham hal ini bisa saja dipengaruhi dengan karateristik industri yang digunakan pada penelitian ini yaitu sub sektor makanan dan minuman. Dimana bahwa Current Ratio bukanlah menjadi ukuran untuk para investor membeli saham. Apabila Current Ratio naik tetapi itu malah 
menjadi potensi beban di masa yang akan datang. Perusahaan makanan dan minuman mengambil keputusan untuk menaikkan stok persediaan karena dikhawatirkan di masa mendatang terjadi kelangkaan stok. Hal ini bisa saja berbahaya untuk perusahaan karena sifat makanan dan minuman bisa saja kadaluarsa. Akibatnya, investor menjadi kurang tertarik untuk membeli saham tersebut, sehingga jumlah permintaan saham akan mengalami penurunan.

Hal ini konsisten dengan penelitian yang dilakukan oleh Dwi Fitrianingsih (2018) yang menunjukkan hasil bahwa current ratio berpegaruh signifikan terhadap harga saham.

\section{Debt to Equity Ratio Berpengaruh Negatif Terhadap Harga Saham}

Berdasarkan hasil uji statistik t pada tabel diatas dapat diketahui bahwa variabel debt to equity ratio mempunyai nilai signifikansi sebesar 0,007 lebih kecil dari 0,05 dan mempunyai nilai t hitung $-2,825$ yang artinya secara parsial variabel debt to equity ratio berpengaruh negatif terhadap harga saham.

Hal ini dapat mengindikasikan adanya pengaruh yang signifikan yang dapat diartikan bahwa besar atau kecilnya total modal yang dimiliki perusahaan untuk dijadikan jaminan total hutang perusahaan tersebut akan berpengaruh terhadap perubahan harga saham, hal ini juga merupakan salah satu faktor yang dipertimbangkan investor dalam berinvestasi. Semakin tinggi rasio ini semakin tinggi resiko kebangkrutan perusahaan, diduga apabila debt to equity ratio turun maka investor tertarik untuk menanamkan modalnya pada perusahaan yang bersangkutan. Pernyataan ini sejalan dengan penelitian terdahulu yang dilakukan oleh Cristin Oktavia Tumandung, dkk (2017) yang menyatakan bahwa debt to equity ratio berpegaruh signifikan terhadap harga saham.

\section{Net Profit Margin Berpengaruh Positif Terhadap Harga Saham}

Berdasarkan hasil uji statistik $\mathrm{t}$ pada tabel diatas dapat diketahui bahwa variabel net profit margin mempunyai nilai signifikansi sebesar 0,000 lebih kecil dari 0,05 dan nilai t tabel sebesar 5,924, artinya secara parsial variabel net profit margin berpengaruh positif terhadap harga saham.

Hal ini dapat mengindikasikan adanya pengaruh yang signifikan antara net profit margin terhadap harga saham yang dapat diartikan semakin naik rasio net profit margin akan berpengaruh terhadap kenaikan harga saham di perusahaan sub sektor makanan dan minuman yang terdaftar di BEI. Pernyataan ini sejalan dengan penelitian terdahulu yang dilakukan oleh Ni Luh Dewi Martiani (2018) yang menyatakan bahwa net profit margin berpegaruh signifikan terhadap harga saham.

\section{Pertumbuhan Perusahaan Tidak Berpengaruh Terhadap Harga Saham}

Berdasarkan hasil uji statistik $\mathrm{t}$ pada tabel diatas diketahui bahwa variabel pertumbuhan perusahaan mempunyai nilai signifikansi sebesar 0,609 lebih besar dari 0,05 dan mempunyai nilai t hitung 0,515 artinya secara parsial pertumbuhan perusahaan tidak berpengaruh terhadap harga saham. Pada penelitian ini, indikator pertumbuhan perusahaan (growth) dilihat dari sisi laba, sedangkan para investor tidak hanya melihat laba sebagi indikator growth yang berdampak pada return di masa depan, karena ada indikator lain yang dapat mempengaruhi harga saham, yaitu dengan melihat pertumbuhan perusahaan dari sisi aset atau penjualan. Pernyataan ini sejalan dengan penelitian terdahulu yang dilakukan oleh Ahmad Ridho Fachrizal 
Chaery (2019) yang mengatakan bahwa pertumbuhan perusahaan tidak berpengaruh terhadap harga saham.

\section{b. Pengujian Hipotesis Simultan (F)}

Uji F dilakukan untuk mengetahui apakah variabel independen (variabel bebas) secara simultan memiliki pengaruh terhadap variabel dependen (variabel terikat). Hasil Uji simultan dalam penelitian ini dapat dilihat pada tabel berikut:

Tabel 3

Hasil Uji F

ANOVA $^{\mathrm{a}}$

\begin{tabular}{|c|c|c|c|c|c|c|}
\hline \multicolumn{2}{|l|}{ Model } & Sum of Squares & df & Mean Square & F & Sig. \\
\hline \multirow{3}{*}{1} & Regression & 49,768 & 4 & 12,442 & 11,581 &, $000^{\text {b }}$ \\
\cline { 2 - 8 } & Residual & 54,794 & 51 & 1,074 & & \\
& Total & 104,562 & 55 & & & \\
\hline
\end{tabular}

Dependent Variable: LN harga Saham

Predictors: (Constant), Pertumbuhan perusahaan, Current Ratio, Net Profit Margin, Debt to Equity Ratio

Berdasarkan dari hasil uji statistik F pada tabel diatas dapat diketahui bahwa current ratio, debt to equity ratio, net profit margin dan pertumbuhan perusahaan mempunyai nilai f hitung sebesar 11,581 dan memiliki nilai signifikasi yang diperoleh adalah 0,000. Dengan demikian variabel current ratio, debt to equity ratio, net profit margin dan pertumbuhan perusahaan secara simultan berpengaruh terhadap harga saham pada perusahaan manufaktur sektor industr barang konsumsi sub sektor makanan dan minuman yang terdaftar di BEI periode tahun 2016 - 2019.

\section{c. Uji Koefisien Determinasi}

Tabel 4

Hasil Uji Koefisien Determinasi $\mathrm{R}^{2}$

\begin{tabular}{|l|r|r|r|r|r|}
\hline Model & R & R Square & Adjusted R Square & $\begin{array}{c}\text { Std. Error of the } \\
\text { Estimate }\end{array}$ & Durbin-Watson \\
\hline 1 &, $690^{\mathrm{a}}$ &, 476 &, 435 & 1,0365284 &, 434 \\
\hline
\end{tabular}

a. Predictors: (Constant), Company's Growth, Current Ratio, Net Profit MARGIN , Debt to Equity Ratio

b. Dependent Variable: LN Harga Saham

Berdasarkan tabel diatas nilai adjudted $\mathrm{R}^{2}$ sebesar 0,435 berarti sekitar 43,5\%. Ini menunjukkan bukti bahwa kemampuan variabel current ratio, debt to equity ratio, net profit margin dan pertumbuhan perusahaan dalam menjelaskan variabel harga saham sebesar $43,5 \%$, sedangkan sisanya $56,5 \%$ dijelaskan atau dipengaruhi oleh faktor-faktor lain diluar penelitian ini.

\section{Kesimpulan}

\section{KESIMPULAN DAN SARAN}

1. Variabel Current Ratio berpengaruh negatif terhadap harga saham selama periode penelitian (2016 - 2019).

2. Variabel Debt to Equity Ratio berpengaruh negatif terhadap harga saham selama periode penelitian (2016 - 2019).

3. Variabel Net Profit Margin berpengaruh positif terhadap harga saham selama periode penelitian $(2016-2019)$. 
4. Variabel pertumbuhan perusahaan tidak berpengaruh terhadap harga saham selama periode penelitian (2016 - 2019).

5. Secara simultan, Current Ratio, Debt to Equity Ratio, Net Profit Margin dan pertumbuhan perusahaan berpengaruh terhadap harga saham selama periode penelitian (2016 - 2019).

\section{Saran}

1. Sampel perusahaan yang digunakan pada penelitian ini hanya pada perusahan Manufaktur sektor Industri Barang Konsumsi sub sektor Makanan dan Minuman, untuk penelitian selanjutnya menggunakan sampel perusahaan manufaktur secara keseluruhan.

2. Variabel yang digunakan dalam penelitian ini adalah current ratio, debt to equity ratio, net profit margin dan pertumbuhan perusahaan, untuk penelitian selanjutnya disarankan hendaknya untuk menambahkan variabel lain seperti pertumbuhan penjualan atau kebijakan deviden karena sangat memungkinkan rasio keuangan yang lain yang tidak dimasukkan dalam penelitian ini berpengaruh terhadap harga saham.

3. Hasil penelitian pada variabel current ratio berpengaruh secara negatif terhadap harga saham, hal ini berbeda dengan pendapat ahli dan konsep teori yang mengatakan current ratio berpengaruh positif terhadap harga saham, untuk itu masih perlu dilakukan penelitan lebih lanjut terkait variabel ini.

\section{DAFTAR PUSTAKA}

Ahmad Ridho Fachrizal Chaery (2019). Analisis Pengaruh Faktor Internal Perusahaan Terhadap Harga Saham Pada Perusahaan Makanan dan Minuman Yang Terdaftar di BEI. Jurnal Ilmiah Akuntansi Universitas Pamulang. Vol.7, No. 2, Juli 2019.

Cristin Oktavia Tumandung, Sri Murni, \& Dedy N. Baramuli. (2017). Analisis Pengaruh Kinerja Keuangan Terhadap Harga Saham Pada Perusahaan Makanan dan Minuman Yang Terdaftar di BEI Periode 2011 - 2015. Jurnal EMBA Vol. 5 No.2 Juni 2017. Universitas Sam Ratulangi.

Dimita H. P. Purba (2017). Pengaruh Pertumbuhan Perusahaan dan Kebijakan Struktur Modal Terhadap Perubahan Harga Saham Pada Perusahaan Property dan Real Estate di BEI. Jurnal Akuntansi dan Keuangan Methodist. Universitas Methodist Indonesia.

Dwi Fitrianingsih (2018). Pengaruh Current Ratio dan Debt to Equity Ratio Terhadap Harga Saham di Perusahaan Food and Beverage Yang Terdaftar di Bursa Efek Indonesia Periode 2013 - 2017. Jurnal Riset Akuntansi Terpadu Vol.12 No,1. Sekolah Tinggi Ilmu Ekonomi Banten. 
Firmansyah \& Masril (2017). Pengaruh Pertumbuhan Perusahaan, Total Asset, Turnover, Return On Invesment, Earning Per Share Terhadap Harga Saham (Studi Perusahaan Manufaktur di BEI).

Ghozali, Imam. 2016. Aplikasi Analisis Multivariete dengan Program IBM SPSS 23 (Edisi 8). Cetakan ke VIII. Semarang : Badan Universitas Diponogoro.

Irawati Junaeni (2017). Pengaruh EVA, ROA, DER dan TATO Terhadap Harga Saham pada Perusahaan Makanan dan Minuman di BEI. Riset dan Jurnal Akuntansi Volume 2 Nomor 1 Agustus 2017. Perbanas - Institute, Economis and Business Faculty.

Irham Fahmi. 2020. Analisis Laporan Keuangan. Cetakan Ketujuh. Bandung : Alfabeta CV.

Irham Fahmi. 2020. Pengantar Manajemen Keuangan Teori dan Soal Jawab. Bandung : Alfabeta CV.

Kasmir. 2018. Analisis Laporan Keuangan. Cetakan Kesebelas. Depok : PT Raja Grafindo Persada.

Ni Luh Dewi Martiani (2018). Pengaruh Rasio Keuangan Terhadap Harga Saham Pada Perusahaan Manufaktur Sektor Industri Barang Konsumsi Yang Terdaftar di Bursa Efek Indonesia Periode Tahun 2013 - 2016. Jurnal Pendidikan Ekonomi Undiksha. Universitas Pendidikan Ganesha.

Rondonuwu Ester Faleria, Linda Lambey, \& Stanley Kho Walandouw. (2017). Pengaruh Current Ratio, Net Profit Margin, dan Earning Per Share Terhadap Harga Saham di Bursa Efek Indonesia (Studi Kasus pada Sub Sektor Food and Beverages). Jurnal Riset Akuntansi Going Concern. Universitas Sam Ratulangi.

Syafri, Sofyan Harahap. 2018. Analisis Kritis Atas Laporan Keuangan. Jakarta : PT Raja Grafindo Persada.

Sukamulja, Sukmawati. 2019. Analisis Laporan Keuangan. Yogyakarta: Andi dan BPFE.

Sulia (2017). Analisis Faktor - Faktor Yang Mempengaruhi Harga Saham Pada Perusahaan LQ45 Yang Tedaftar di Bursa Efek Indonesia. Jurnal Wira Ekonomi Mikrosil. Akuntansi STIE Mikrosil.

Website : $\underline{w w w . i d x . c o . i d}$ 